\title{
Correction to: Intelligence augmentation: rethinking the future of work by leveraging human performance and abilities
}

\section{David Harborth $^{1}$ (D) Katharina Kümpers ${ }^{1}$}

Published online: 16 December 2021

๑) Springer-Verlag London Ltd., part of Springer Nature 2021

\section{Correction to: Virtual Reality}

https://doi.org/10.1007/s10055-021-00590-7

In the original publication the citations of Figs. 1 and 2 and their captions are wrongly published.

The correct Fig. 1 caption should read as "A framework for using AR and VR in workforce training (images are own representations)", and correct Fig. 2 caption should read as, "Jobs losses and gains of the 'Economic 4.0' scenario compared to the basic scenario (Wolter et al. 2016)".

The citation of Fig. 1 should be cited under Sect. 4, and citation of Fig. 2 should be cited under Sect. 2.2. The original publication has been corrected.
The original article can be found online at https://doi.org/10.1007/ s10055-021-00590-7.

Dr. David Harborth

david.harborth@m-chair.de

1 Goethe University, Theodor-W.-Adorno-Platz 4, 60323 Frankfurt am Main, Germany
Publisher's Note Springer Nature remains neutral with regard to jurisdictional claims in published maps and institutional affiliations. 